\title{
Growing tendency to harmonisation with IFRS: some evidences from Turkey
}

\author{
Mehmet C. Kocakülâh* \\ College of Business, \\ University of Southern Indiana, \\ 8600 University Blvd., Evansville, IN 47712, USA \\ Fax: 812-465-1044_E-mail: mkocakul@usi.edu \\ *Corresponding author
}

\section{Can Şımga-Muğan}

Department of Business Administration,

Middle East Technical University,

Inonu Bulvarı, Ankara, 06531, Turkey

E-mail: mugan@metu.edu.tr

\section{Nazli Hoşal-Akman}

Faculty of Business Administration,

Bilkent University,

Bilkent, Ankara, 06533, Turkey

E-mail: nakman@bilkent.edu.tr

\section{Mehtap Aldogan}

Ernst \& Young LLP,

200 Clarendon Street, Boston, MA 02116, USA

E-mail: mehtap.aldogan@ey.com

\begin{abstract}
Motivated by the recent developments in accounting regulations, we explore the tendency of countries to converge to IFRS for both public and private companies and present some evidence on the issue from an emerging market. We explore how the legal system - civil vs. common law - and the stock market development stage in a country affects the acceptance of IFRS by the regulators. We find that stock market influences the acceptance of IFRS for both public and private companies while the legal system affects the requirement of IFRS for the private companies. In Turkey, different regulatory bodies control different types of companies. Capital Markets Board that controls the listed companies issued the first set of translated IFRS in 2003. Established in 2002, Turkish Accounting Standards Board (TASB) is responsible to translate and issue the international accounting standards. Examination of issue and effective dates of both standards reveals that TASB closely follows the IASB efforts.
\end{abstract}

Keywords: international financial reporting standards; IFRS; legal system; harmonisation; convergence; Turkey. 
Reference to this paper should be made as follows: Kocakülâh, M.C., Şımga-Muğan, C., Hoşal-Akman, N. and Aldogan, M. (2009) 'Growing tendency to harmonisation with IFRS: some evidences from Turkey', Int. J. Managerial and Financial Accounting, Vol. 1, No. 4, pp.398-422.

Biographical notes: Mehmet C. Kocakülâh, $\mathrm{PhD}$, is a Professor of Accountancy at the University of Southern Indiana, Evansville, Indiana.

Can Şımga-Muğan is a Professor of Accountancy at Middle East Technical University, Department of Management.

Nazlı Hoşal-Akman is an Instructor at Bilkent University, Faculty of Business Administration teaching Financial and Managerial Accounting and Financial Statement Analysis both at graduate and undergraduate levels.

Mehtap Aldogan is an Audit Senior 1 and 2 at Ernst \& Young LLP.

\section{Introduction}

The international economic activity has been increasing at a rapid rate in line with the winds of globalisation. International trade, capital movements among countries, international investments, the number of multinational corporations and international bond and equity offerings exhibited a huge growth over the last decade. For instance, the number of multinational corporations doubled from 1996 to 2006 from 30,000 to 60,000 while their sizes got smaller (Copeland, 2007) ${ }^{1}$. Similarly, the value of International Equity Offerings for the total market from five geographic regions increased about threefold in the late 1990s (Basoglu and Goma 2000). Due to internationalisation, a global capital market is in the process of being formed with a high degree of integration and cooperation between national centres. In other words, the erosion of national barriers in financial markets triggered the need for relevant financial information to compare investment opportunities of different nature and for a single set of high quality, understandable and enforceable global accounting standards that require transparent and comparable information in financial statements (Murtaza 2006; Katz 2000).

The effect of using different accounting standards is very well illustrated by the Daimler-Benz case. In 1993, Daimler-Benz applied for the official quotation into the New York Stock Exchange. The company declared 615 million Deutsche Mark (DM) incomes according to German General Accepted Accounting Principles (GAAP) while the financial statements prepared for the same period in accordance with the US GAAP produced an income of 1,839 million DM (Ibis and Ozkan, 2006). Another example is Turkcell which is a multi-national telecommunication corporation headquartered in Turkey, quoted at both the Istanbul Stock Exchange (ISE) and the New York Stock Exchange. In 2000 the Company reported USD 276 million losses and USD 227 million incomes at ISE and New York Stock Exchange respectively ${ }^{2}$.

There is almost total consensus on the benefits of using of one global set of accounting standards. It is expected that the recent set of international accounting standards (IAS) provide comparable, relevant, timely and reliable information for the entrepreneurs, investors and multi-national corporations (MNCs) to help them make precise decisions (Andersen et al., 2001; Zeghal and Mhedhbi, 2006; Murtaza, 2006; 
Petreski, 2006). The way leading to a single set of globally accepted standards followed two main paths - harmonisation and convergence. Convergence is the process of transition from the host accounting jurisdiction to International Financial Reporting Standards (IFRS). To Choi et al. (2002), harmonisation of accounting principles is the process of 'increasing the compatibility of accounting practices by setting limits on how much they can vary' (Murtaza, 2006). In other words, countries modify their national accounting standards to achieve more comparability with other countries financial statements where there could be leader country practices - such as the US GAAP and follower country practices. However, as stated by Securities and Exchange Commission (SEC) 'convergence' means that all standards setters would agree on a single and a high quality answer (Herdman, 2002). In this paper, we will choose to use the term convergence to signify the latest efforts.

This study is motivated by the augmentation in international economic activities, globalisation of capital markets, the convergence efforts for a single set of transparent, compatible, comparable and high quality accounting standards around the world. There are two main purposes of the study: first, to determine the latest convergence efforts around the world and secondly to discuss the convergence activities in an emerging market, Turkey. In the exploration of the answer to the first question, we try to establish a relationship between the legal structure and stock market development on one hand and IFRS permission and enforcement for the publicly traded and private companies around the world on the other hand. In this paper, we chose Turkey as a case to discuss the convergence efforts in detail because it is an emerging market with an increasing foreign portfolio investment by the international investors as depicted in Table 1 .

This study is organised as follows: Section 2 provides a glance at International Accounting Standards Board (IASB) and IFRS. In Section 3, the convergence endeavours around the world, including the pros and cons, are discussed. Section 4 reports and discusses the IFRS permission and enforcement around the world. Section 5 presents evidence of convergence from Turkey. Finally, Section 6 is the succinct conclusion.

Table 1 Foreign portfolio investment in ISE

\begin{tabular}{lccc}
\hline & Purchases & Sales & Net investment \\
\cline { 2 - 4 } & US\$ million & US\$ million & US\$ million \\
\hline 1997 & 4,308 & 4,609 & $(301)$ \\
1998 & 5,626 & 6,044 & $(418)$ \\
1999 & 9,452 & 8,428 & 1,024 \\
2000 & 15,138 & 18,272 & $(3,134)$ \\
2001 & 6,324 & 5,815 & 509 \\
2002 & 6,427 & 6,442 & $(15)$ \\
2003 & 9,172 & 8,162 & 1,010 \\
2004 & 19,399 & 17,969 & 1,430 \\
2005 & 42,594 & 38,507 & 4,087 \\
2006 & 44,832 & 43,687 & 1,144 \\
$2007-J a n-O c t$ & 62,392 & 57,507 & 4,885 \\
\hline
\end{tabular}

Source: http://www.ise.org/data.htm 


\section{A glance at International Accounting Standard Board and IFRS}

The IASB, formerly the International Accounting Standards Committee (IASC) established in 1973, is the body that sets IFRS (Murtaza, 2006). In 1973, IASC has been established with the agreement of the representatives of the professional accountancy bodies in Australia, Canada, France, Germany, Japan, Mexico, Netherlands, UK, Ireland and USA (Murtaza, 2006). In 1975, first IAS, IAS 1 and IAS 2, were published. On April 1, 2001 IASB assumed the responsibilities of IASC. As of January 2007, eight IFRS and 29 IAS are in effect ${ }^{3}$. IASB essentially represents an Anglo-Saxon model of financial disclosure and measurement (Flower, 1997). Therefore, the legal environment in a country becomes very important for the decision to adopt the standards issued by IASB.

IASB is an independent private organisation working to achieve a degree of comparability that will help international investors with their investment decisions while reducing the cost of preparing multiple sets of financial statements entities. To attain this purpose IASB set the following objectives in its constitution ${ }^{4}$ :

a to develop, in the public interest, a single set of high quality, understandable and enforceable global accounting standards that require high quality, transparent and comparable information in financial statements and other financial reporting to help participants in the world's capital markets and other users make economic decisions

$\mathrm{b}$ to promote the use and rigorous application of those standards

c in fulfilling the objectives associated with (a) and (b), to take account of, as appropriate, the special needs of small and medium-sized entities and emerging economies

d to bring about convergence of national accounting standards and IAS and IFRS to high quality solutions.

IASB seems to be successful in achieving its objectives as several countries adopt IAS as their national standards or use them while developing their national standards. Approximately 100 countries require or allow the use of IAS for the preparation of financial statements or have a convergence plan with $\mathrm{IAS}^{5}$. Among those countries are Australia, European Union (EU) members, South Africa and Russia. Although, IASB does not currently have the power of enforcing the use of IFRS, various national capital market board regulators initiated the use of such standards in preparation of the financial statements (Holzmann and Robinson, 2004).

In addition to IASB, another globally important standard setting body is Financial Accounting Standards Board (FASB) in the US. Since 1973, the FASB has been the designated organisation in the private sector for establishing financial accounting and reporting standards. For publicly held companies listed in the US, the SEC has statutory authority to establish financial accounting and reporting standards under the Securities Exchange Act of 1934, as well (FASB, 2006).

FASB has issued 160 Financial Accounting Standards (FAS) ${ }^{6}$. Like IASB, the mission of FASB is to establish and improve standards of financial accounting and reporting for the guidance and education of the public, including issuers, auditors and users of financial statements. As Foster (1993), FASB Member addressed, by fulfilling that role, it helps reduce uncertainty, lower the cost of capital for decision-makers and 
investors and provide neutral and credible information and it enables economic resources to be allocated as efficiently as possible.

US GAAP are overly detailed and 'rules-based' while IFRS/IAS are 'principle-based' (Schipper, 2005). After the confidence in corporate the USA was shattered after accounting troubles, such as Enron, WorldCom, etc., the accountancy bodies around the world prefer more to-the-point and principle-based accounting standards to harmonise their national GAAP. Paul Cherry, chairman of the Canadian Accounting Standards Board (ACSB), mentions that the time is ripe to stop convergence with US GAAP and open Canada's arm to more principle-based global standards, namely IFRS, because accounting scandals, for example Enron and WorldCom, have exposed the weakness of the rules-based approach (Middlemiss, 2006).

The corporate fiascos in the USA further influenced FASB to converge their standards with IFRS in 2002. In particular, at a joint meeting in September 2002, the IASB and the FASB issued their 'Norwalk Agreement' and agreed to work together to develop high quality, fully compatible financial reporting standards that could be used for domestic and cross-border reporting (Schipper, 2005; IASB, 2006). Besides, at their meetings in April and October 2005, the FASB and the IASB reaffirmed their commitments to convergence of US GAAP and IFRS (IASB, 2006).

In summary, there are two main accountancy bodies in the World, IASB and FASB. Both have prescribed their own GAAPs. On the other hand, due to the recent failures in the businesses in the globe, the world has a growing tendency to align their host jurisdictions with 'principle-based' IFRS. More importantly, the FASB has a same point of view. That is why convergence with IFRS becomes a much-debated issue of this millennium.

\section{Convergence}

Harmonisation of accounting standards was the centrepiece of the efforts to build a global financial reporting infrastructure (Day, 2002). As stated by Mr. Paul Volcker, Chairman of the Trustees of the IASC Foundation in 2001 the rapid development of global financial markets has greatly reinforced the desirability of international consistency in accounting standards all over the world (Andersen et al., 2001). Hence, leading to convergence of accounting standards globally.

The benefits that would be brought by convergence can be analysed from different perspectives. From international investors' point of view, convergence with IFRS would help in raising foreign capital, understanding the financial statements of foreign companies and comparing the investment portfolios in different countries. For example, the Turkish company that is traded in both ISE and NYSE - Turkcell - reported the same amount of income at both markets except for the minor to differences due to currency fluctuations in translation of statements for the three quarter income figures in $2007^{7}$. Multi-national corporations (MNCs) would also benefit from the convergence of accounting standards. It would be easier for them to communicate with other group companies with the understandable, transparent and comparable financial statements which would also lead to easy consolidation of subsidiaries, Furthermore appraisal of foreign take-overs and mergers, conduct of competitive and operational analyses, better management controls and transfer the accounting staff across national borders would be 
at ease upon convergence. The reduction in audit costs may also be an outcome of convergence (Andersen et al., 2001).

Thirdly, convergence will benefit governmental institutions and national standard setters, as full adoption of IAS would save time and money. It ensures accountability and transparency of operations of enterprises in different countries and assists governments in attracting international investors by enabling them to monitor the overseas investments easily (Taylor et al., 1986; Peavy and Webster, 1990; Andersen et al., 2001). Besides, for the tax authorities, it would be easy to calculate the tax liability of investors and organisations if net income was computed on similar accounting principles and practices (Andersen et al., 2001). Finally, common accounting practices would help to promote cross border trade within regional trade groups.

In addition to bringing benefits to various parties, convergence also has certain drawbacks. Culture, legal systems, economic and political circumstances are among the most important differences between countries (Schipper, 2005). International accounting literature has been discussing variances in accounting practices arising from such differences for a long time. It's been argued that the use of IFRS will create problems, as it does not addresses national differences (Perera, 1989). A common belief is that one size may not fit all. IFRS is also criticised for being extremely complex and thus requiring high degree of management judgment (Larson and Street, 2004).

The results of initial implementation of IFRS by the European companies are promising though. Financial analysts were satisfied from the financial statements and asserted that convergence will bring transparency and comparability (PricewaterhouseCoopers, 2006).

In the US, the use of IFRS is not permitted for the US based corporations yet. Nevertheless, as indicated above, the IASB and the FASB already embarked on a joint program to converge US GAAP and IFRS to the maximum extent possible. In November 15, 2007, SEC stated that:

\footnotetext{
"Having considered extensive and informative public comment on its June 2007 proposal, the Commission today approved rule amendments under which financial statements from foreign private issuers in the US will be accepted without reconciliation to US GAAP only if they are prepared using IFRS as issued by the IASB."
}

This is a major step to convergence of accounting standards globally. Further, IASB announced that the Board is not going to require any new standards or major changes in the existing standards to be in effect before $2009^{9}$. Such an effort will give the preparers a period to adjust to the developments and to provide the country regulators with some time to prepare the legal structure to apply IFRS or its equivalent.

EU, in 2002 approved an accounting regulation requiring all EU companies listed on a regulated market (about 8,000 companies in total) to follow IFRSs in their consolidated financial statements starting in 2005 (EU, 2002; Deloitte, 2006a). At the time about 10\% of these companies were using either IAS or US accounting standards (Van Helleman and Slomp, 2002).

Currently, domestic Canadian companies listed in the USA are allowed to use US GAAP for domestic reporting, but not IFRSs. In January 2006, the Accounting Standards Board of Canada announced a plan to replace Canadian GAAP with IFRSs for listed companies over the next five years (Deloitte, 2006b). 
Asia-Pacific jurisdictions are also taking a variety of approaches toward convergence of GAAP with IFRSs. Only Bangladesh requires IFRS for all domestic listed companies. Australia, Hong Kong, New Zealand and the Philippines revised their national standards that are virtually similar to IFRSs word-by-word. Singapore has adopted most IFRS's word for word, but has modified several including IAS's 16, 17, 39 and 40. India, Malaysia, Pakistan, Sri Lanka and Thailand have adopted selected IFRS quite closely, but significant differences exist in other national standards and there are time lags in adopting new or amended IFRS (Deloitte, 2006a). Furthermore, China, Indonesia, Japan, Korea, Taiwan and Vietnam have convergence attempts at various degrees, but significant differences exist among the countries. In February 2006, China adopted a new basic standard and 38 new Chinese Accounting Standards consistent with IFRSs with few exceptions (Deloitte, 2006a).

Overall, even though each country has its own approach towards convergence and even some countries do not permit the use of IFRS yet, we believe that, slowly but steadily, countries are moving to the convergence to IAS in their own way as demonstrated in the latest case of SEC pronouncement for foreign listed companies.

\section{Analysis of converge globally}

In this second part of the paper, we will explore the convergence activities of various countries. Our aim in this investigation is to determine whether there is an association between the legal environment and the development stage of the stock market of a country on one hand and the permission or enforcement of IFRS for both traded and private companies. We first classified the countries according to their stock market development stage according to MSCI-Barra taxonomy ${ }^{10}$, - emerging developed and G7 countries.

The 'law and finance' theory [Graff, (2005), p.1] states that there is link between the financial development and legal system and that common law system generally provides a more conducive basis for financial development than the civil law tradition. La Porta et al. (1997) declare that they find strong evidence that legal framework affects capital market breath and size; and they find that French origin civil laws offer the least protection for investors and thus less conducive to financial market growth. Graff (2005), although skeptical of the theory, finds that the legal system affects the way the shareholders' rights are protected - not better in any system but different. Following this intuitively appealing 'law and finance' theory paradigm, we explore whether there is a legal system and financial reporting paradigm. Specifically, we investigate whether there is an association between the legal system and the permission or requirement of IFRS for both traded and private companies. We adopt the taxonomy used in La Porta et al. (1997) and later by Graff (2005) to classify the countries as either a 'Common Law' or a 'Civil Law' (code based) country. If a country is not found in the Graff study, we study its legal system and classify it according to the common characteristics. Table 2 summarises the classification we use in this study. In our analysis, we use a dichotomous system for the legal framework - 'civil' versus 'common' - using the taxonomy provided in La Porta et al. (1997). 
Table 2 Classification system

\begin{tabular}{|c|c|c|c|c|}
\hline \multirow{2}{*}{$\begin{array}{l}\text { Emerging } \\
\text { markets }\end{array}$} & \multirow{2}{*}{$\frac{\text { Common law }}{\text { English origin }}$} & \multicolumn{3}{|c|}{ Civil law } \\
\hline & & French origin & German origin & $\begin{array}{c}\text { Scandinavian } \\
\text { origin }\end{array}$ \\
\hline Argentina & & $\mathrm{x}$ & & \\
\hline Brazil & & $\mathrm{x}$ & & \\
\hline Chile & & $\mathrm{x}$ & & \\
\hline China & & & $\mathrm{x}$ & \\
\hline Colombia & & $\mathrm{x}$ & & \\
\hline Czech Republic & & & $\mathrm{x}$ & \\
\hline Egypt & & $\mathrm{x}$ & & \\
\hline Hungary & & & $\mathrm{x}$ & \\
\hline India & $\mathrm{x}$ & & & \\
\hline Indonesia & & $\mathrm{x}$ & & \\
\hline Israel & $\mathrm{x}$ & & & \\
\hline Jordan & & $\mathrm{x}$ & & \\
\hline Korea & & & $\mathrm{x}$ & \\
\hline Malaysia & $\mathrm{x}$ & & & \\
\hline Mexico & & $\mathrm{x}$ & & \\
\hline Morocco & & $\mathrm{x}$ & & \\
\hline Pakistan & $\mathrm{x}$ & & & \\
\hline Peru & & $\mathrm{x}$ & & \\
\hline Philippines & & $\mathrm{x}$ & & \\
\hline Poland & & & $\mathrm{x}$ & \\
\hline Russia & & $\mathrm{x}$ & & \\
\hline South Africa & $\mathrm{x}$ & & & \\
\hline Sri Lanka & $\mathrm{x}$ & & & \\
\hline Taiwan & & & $\mathrm{x}$ & \\
\hline Thailand & $\mathrm{x}$ & & & \\
\hline Turkey & & & $\mathrm{x}^{*}$ & \\
\hline Venezuela & & $\mathrm{x}$ & & \\
\hline
\end{tabular}

Notes: *Although La Porta et al. (1997) classifies Turkey as French origin, Turkish Commercial Law is based on the Swiss laws, which are based on the German laws. 
Table 2 Classification system (continued)

\begin{tabular}{|c|c|c|c|c|}
\hline \multirow{2}{*}{$\begin{array}{l}\text { Developed } \\
\text { markets }\end{array}$} & \multirow{2}{*}{$\frac{\text { Common law }}{\text { English origin }}$} & \multicolumn{3}{|c|}{ Civil law } \\
\hline & & French origin & German origin & $\begin{array}{c}\text { Scandinavian } \\
\text { origin }\end{array}$ \\
\hline Australia & $\mathrm{x}$ & & & \\
\hline Austria & & & $\mathrm{x}$ & \\
\hline Belgium & & $\mathrm{x}$ & & \\
\hline Denmark & & & & $\mathrm{x}$ \\
\hline Finland & & & & $\mathrm{x}$ \\
\hline Greece & & $\mathrm{x}$ & & \\
\hline Hong Kong & $\mathrm{x}$ & & & \\
\hline Ireland & $\mathrm{x}$ & & & \\
\hline Netherlands & & $\mathrm{x}$ & & \\
\hline New Zealand & $\mathrm{x}$ & & & \\
\hline Norway & & & & $\mathrm{x}$ \\
\hline Portugal & & $\mathrm{x}$ & & \\
\hline Singapore & $\mathrm{x}$ & & & \\
\hline Spain & & $\mathrm{x}$ & & \\
\hline Sweden & & & & $\mathrm{x}$ \\
\hline Switzerland & & & $\mathrm{x}$ & \\
\hline \multicolumn{5}{|l|}{ G7 Countries } \\
\hline Canada & $\mathrm{x}$ & & & \\
\hline France & & $\mathrm{x}$ & & \\
\hline Germany & & & $\mathrm{x}$ & \\
\hline Italy & & $\mathrm{x}$ & & \\
\hline Japan & & & $\mathrm{x}$ & \\
\hline UK & $\mathrm{x}$ & & & \\
\hline USA & $\mathrm{x}$ & & & \\
\hline
\end{tabular}

Notes: *Although La Porta et al. (1997) classifies Turkey as French origin, Turkish Commercial Law is based on the Swiss laws, which are based on the German laws. 
Table 3 Legal framework and permission and requirement of IFRS

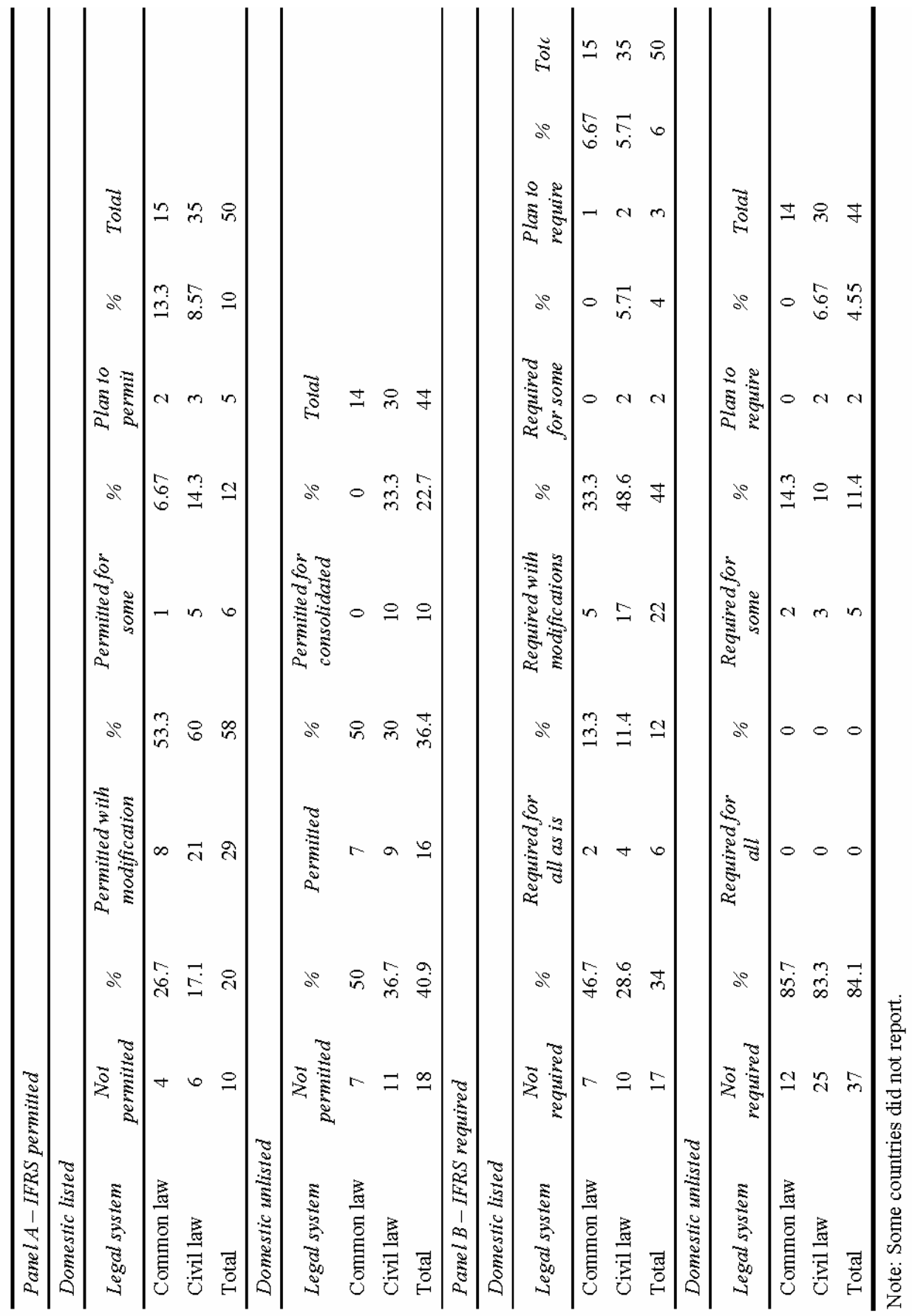


We obtained the country data from IAS Plus ${ }^{11}$ where '...reports direct use of IFRS in individual countries or regions. Direct use means that the basis of preparation note and the auditor's report will refer to conformity with IFRS (for the listed companies)' and for unlisted companies, 'IFRS required for all means that if an unlisted company is required or chooses to prepare general purpose financial statements, it must use IFRS. It does not necessarily mean that all unlisted companies in that jurisdiction are required to prepare IFRS financial statements'. In the absence of a more comprehensive survey of country practices, we believe this information provides an initial base for exploring the association we are interested in.

We first explored the association between the legal framework and IFRS permission or requirement for the listed companies. Table 3 summarises the results.

We conducted chi-square tests to determine the statistical significance of the association between the legal system and the IFRS permission and requirement in domestic listed (from now on listed) or publicly traded and domestic unlisted (from now on unlisted) or private companies. Legal system does not seem to affect the permission of IFRS for the listed companies. IFRS are permitted in about $60 \%$ of the countries regardless of the legal system and about $10 \%$ of the countries plan to permit the use of IFRS for the listed companies the latest by either 2009 or 2011 although in $20 \%$ of the countries IFRS are not permitted. $49 \%$ of the civil law and $33 \%$ of the common law countries require IFRS with modifications and only $12 \%$ of the countries require IFRS as is while $40 \%$ of the countries do not require IFRS. However, the difference between the civil law and common law countries is not statistically significant.

Unlike the findings for the listed companies, the legal environment affects the permission to use IFRS in unlisted companies $(p=0.047)$ where $50 \%$ of the common law countries and $30 \%$ of the civil law countries permit the use of IFRS. However, the same significance is not found in the case of requiring the use of IFRS. None of the countries require the use of IFRS for all the companies while only $18 \%$ of the common law countries and $10 \%$ of the civil law countries require the use of IFRS for some of the unlisted companies (see Table 3). Consequently, we may state that the legal system does not influence the requirement of IFRS either for the listed companies or for the unlisted companies.

Next, we explore the association between the level of stock market development and IFRS permission and requirement for the listed and the unlisted companies regardless of the legal environment. As mentioned above, we used MSCI Barca indices - emerging, developed and G7 countries - to select the countries to investigate. The classification is presented in Table 2 above and in Table 4.

Table 4 Distribution of countries

\begin{tabular}{lcccc}
\hline Legal system/stock market & Emerging & Developed & $G 7$ & Total \\
\hline Common law & 7 & 5 & 3 & 15 \\
Civil law & 20 & 11 & 4 & 35 \\
Total & 27 & 16 & 7 & 50 \\
\hline
\end{tabular}

Chi-square test results show that stock market development stage significantly affects the permission of IFRS for both the listed $(p=0.065)$ and unlisted $(p=0.000)$ companies. About $56 \%$ of the emerging market countries permit the use of IFRS either for all or some of the domestic listed companies. All of the developed market countries allow IFRS 
either for all or for some of the listed companies while two G7 countries (Japan and the USA) do not permit the domestic listed companies to use IFRS as shown in Table 5.

Table 5 Stock market development stage and permission and requirement of IFRS

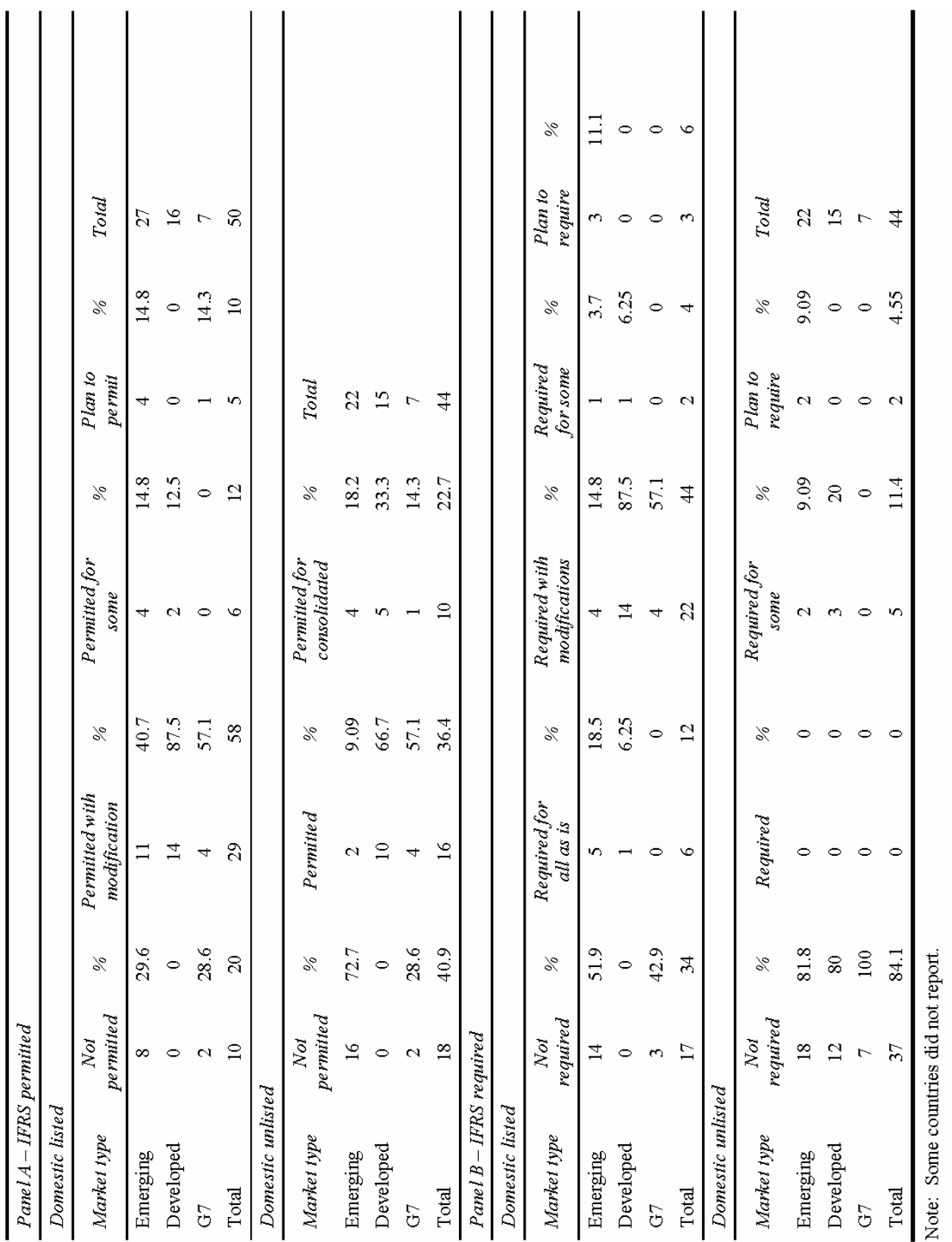


Statistical tests show that development stage of the stock market has an effect on the requirement of the IFRS by the authorities $(p=0.001)$. Although, none of the G7 countries require the use of IFRS as is for the listed companies, it is interesting to note that about $19 \%$ of the emerging market countries do. On the other hand, $87.5 \%$ of the developed market countries require the use of IFRS with modifications for the listed companies.

Although $72.7 \%$ of the emerging market countries do not permit the use of IFRS for the unlisted companies, all of the developed countries and five of the G7 countries allow the unlisted companies to use IFRS either for all or for the consolidated reports. This significant finding shows the diversity in the acceptance of IFRS in markets with different development stage $(p=0.000)$. However, none of the countries require the unlisted companies to use IFRS while only two emerging countries (Poland and Russian Federation) and three countries with developed markets (Australia, Belgium and New Zealand) require IFRS for some of the unlisted companies. These findings indicate that stock market developments have a greater effect than the legal environment on the enforcement and acceptance of IFRS for the listed companies. When we consider the effect of IOSCO in establishing a single set of accounting standards, this observation should not be surprising. Moreover, previous research has demonstrated that developing countries that have capital markets have a strong and positive effect on the adoption decision (Zeghal and Mhedhbi, 2006). On the other hand, both legal environment and the stock market development stage seem to influence the treatment for the unlisted companies.

In the next section, we will discuss the convergence efforts, regulatory environment and stock market development in Turkey. Despite the fact that Turkey has not been a member state of the EU yet and the accounting diversity of the Turkish nation, e.g., culture and religion, etc., is different from Europe and USA, she has a remarkable enthusiasm for convergence to IFRS. Therefore, activities taking place in Turkey is a noteworthy evidence of convergence.

\section{Evidence of convergence from Turkey}

The reasons we chose to study Turkey are manifold. First, the average returns of emerging markets are almost $50 \%$ higher than the returns of developed markets over the last two decades (Harvey, 1995; Simga-Mugan and Hosal-Akman, 2005). Even very recently in 2007, the US equity returns were $5.5 \%$ while the emerging stock market returns were $39.39 \%{ }^{12}$. Turkey is also emerging market that attracts international investors as mentioned earlier in the paper (see Table 1) where investors enjoyed a return of $74.1 \%$ in 2007 (after Peru $-94 \%)^{13}$. These returns demonstrate why nowadays the emerging markets are gaining in popularity by the international investors.

The second reason of selecting Turkey is her determination to apply IFRS (or its equivalent translation) to the listed companies where early adoption was encouraged in 2003 and compulsory application in 2005 parallel to the European regulations (Simga-Mugan and Akman, 2007). To discover the countries' ambition and preparedness for IFRS adoption, Mazars Accountancy Firm surveyed 550 listed companies in 12 European countries in April 2005. Based on that survey, Turkish companies are found to be very willing to apply IFRS for their financial reporting where $56 \%$ already used IFRS 
and $20 \%$ plan to change over in the near future. These rates are the highest in Europe in terms of acceptance of convergence (Mazars, 2005).

The third reason is the considerable increase in the number of companies with foreign capital (FCC) since the 'Foreign Direct Investment Law No. 4875' came into power on June 17, 2003. The number of 'FCC' established between June 17, 2003 and December 31,2005 is $101 \%$ more than that of the previous years' total number (Turkish Treasury, $2005,2006)$. As of 2005, 9,684 corporations and/or branch offices with foreign capitals has been established in Turkey. In addition, 2,001 foreign capital participations to the existing companies incurred. In simpler terms, as depicted in Table 6, the 11,685 FCC are in operation in Turkey (Turkish Treasury, 2005, 2006).

Table 6 Number of FCC

\begin{tabular}{lc}
\hline Dates & Number \\
\hline $1954-1999$ (cumulative) & 4,192 \\
2000 & 455 \\
2001 & 484 \\
2002 & 495 \\
2003 & 1,105 \\
2004 & 2,129 \\
2005 & 2,825 \\
Total & 11,685 \\
\hline
\end{tabular}

Source: Turkish Treasury (2005)

As well as the FCC, increase in the foreign direct investment (FDI) capital inflow is the other reason that makes international investors in Turkey urge for single set of transparent and compatible financial information. To illustrate, as seen in Table 7, in 2005, the FDI capital inflow soared from 1,245 million dollar in 2004 to 8,409 million dollar in 2005 (Turkish Treasury, 2005).

Table 7 Breakdown of FDI capital inflow by country group

\begin{tabular}{lcccc}
\hline Dates & EU countries & $\begin{array}{c}\text { Other OECD } \\
\text { countries }\end{array}$ & Other countries & Grand total \\
\hline 1995 & 704 & 218 & 12 & 934 \\
1996 & 491 & 229 & 194 & 914 \\
1997 & 522 & 290 & 40 & 852 \\
1998 & 553 & 391 & 9 & 953 \\
1999 & 386 & 258 & 169 & 813 \\
2000 & 1,172 & 210 & 325 & 1,707 \\
2001 & 2,640 & 339 & 395 & 3,374 \\
2002 & 455 & 138 & 29 & 622 \\
2003 & 566 & 176 & 3 & 745 \\
2004 & 981 & 210 & 54 & 1,245 \\
2005 & 4,766 & 1,994 & 1,649 & 8,409 \\
\hline
\end{tabular}

Note: Million \$.

Source: Turkish Treasury (2005) 
Before concentrating on the current attempts to internationalisation and convergence, brief information regarding laws and regulations has been provided to help understand the following parts more easily in Turkey. Historically, Turkish accounting system fell under the influence of the French, German and the US system. In the first years of the Republic commercial code and tax laws has been written based on the Swiss and German laws; and hence, Turkey is a civil law country under the German influence. The first set of accounting standards were published by the Capital Markets Board (CMB) in 1989 (Series XI, No. 1), which were in line with the IAS of the time reflecting the Anglo-Saxon influence. For more information on the historical development please refer to Simga-Mugan and Akman (2007), Simga-Mugan and Hosal-Akman, (2005), Simga-Mugan (1995) and Aksu and Kosedag (2005).

There are various regulatory bodies govern the accounting and reporting environment in Turkey: the tax and commercial law setters or legislators, CMB, the Banking Regulation and Supervision Agency (BRSA) and Turkish Accounting Standards Board (TASB). For the all profit-oriented companies, it is mandatory to be in accord with the Commercial Code and the Procedural Tax Law. These companies must also meet the requirements of Ministry of Finance's regulations. Banks are subject to the regulations of BRSA. Publicly traded companies and financial intermediaries are regulated by the CMB rules for financial reporting purposes while they follow the above-mentioned rules for tax reporting (Anil 2000; Ibis and Ozkan 2006; Simga-Mugan and Akman, 2007). Turkey is currently in the process of changing the Commercial Code. The draft Commercial Code that requires all companies to use Turkish Accounting Standards (TAS) that issued by TASB is on the floor for discussion at the Parliament as of June 2008.

CMB issued a communiqué in 2003 requiring all publicly traded companies to comply with the new set of accounting standards (Series XI, No. 25) ${ }^{14}$ that were translations of IFRS at the time with a few modifications to be in effect starting 2005 and permitted early adoption of the new standard or the use of IFRS as issued by IASB. Table 8 lists the standards of CMB for the publicly traded companies. As we observe from the table, CMB standards closely follow the IAS as of 2003. As of April 2008, CMB issued a new communiqué requiring the publicly traded to apply Turkish Financial Reporting/Accounting Standards as long as they are in line with the accepted version of IFRS in the EU.

For the banks, the BRSA requires the use of TAS and International Convergence of Capital Measurement and Capital Standards: A Revised Framework, commonly known as Basel II (Ibis and Ozkan 2006; BIS 2006).

Third standard setter is the TASB in Turkey that was established in 2002, to issue the TAS. The Board has nine representatives from the Ministry of Finance, Higher Education Council, the CMB, the Undersecretariat of Treasury, Ministry of Industry and Commerce, the BRSA, the Union of Chambers and Commodity Exchanges in Turkey (TOBB), a self employed accountant and a certified financial consultant from Union of Certified Public Accountants and Sworn-in Certified Public Accountants in Turkey (TURMOB) (Simga-Mugan and Akman, 2007). As the official translator, TASB had the standards translated into Turkish 'as is with no changes or modifications' and had the standards published in the Official Gazette (of the Turkish Republic). The Board also issues the changes in the international standards as amendments and has them published in the Official Gazette. Presently TASB issued 29 TAS and eight Turkish Financial Reporting Standards (TFRS) ${ }^{15}$. All of these issued standards correspond to respective IAS 
and IFRS. Once promulgated, the new Commercial Code will make TASB's standards mandatory for all companies (Ibis and Ozkan 2006).

Table 8 The accounting standards of the Capital Market Board (CMB) - Series XI, No. 25

\begin{tabular}{|c|c|c|}
\hline Section Number & Description of CMB Standards & IFRS \\
\hline Section 1 & $\begin{array}{l}\text { Framework for the preparation and } \\
\text { presentation of financial statements }\end{array}$ & \\
\hline Section 2 & Presentation of financial statements & IAS 1 \\
\hline Section 3 & Interim financial reporting & IAS 34 \\
\hline Section 4 & Cash flow statements & IAS 7 \\
\hline Section 5 & Revenue & IAS 18 \\
\hline Section 6 & Inventories & IAS 2 \\
\hline Section 7 & Property, plant and equipment & IAS 16 \\
\hline Section 8 & Intangible assets & IAS 38 \\
\hline Section 9 & Impairment & IAS 36 \\
\hline Section 10 & Borrowing costs & IAS 23 \\
\hline Section 11 & Financial instruments & IAS 32 and IAS 39 \\
\hline Section 12 & Business combinations & IAS $22 *$ \\
\hline Section 13 & $\begin{array}{c}\text { Consolidated and separate financial } \\
\text { statements and investments in associates } \\
\text { and joint venture }\end{array}$ & $\begin{array}{l}\text { IAS } 27 \text { and IAS } 28 \\
\text { and IAS } 31\end{array}$ \\
\hline Section 14 & $\begin{array}{c}\text { The effects of changes in foreign exchange } \\
\text { rates }\end{array}$ & IAS 21 \\
\hline Section 15 & $\begin{array}{c}\text { Financial reporting in hyperinflationary } \\
\text { economies }\end{array}$ & IAS 29 \\
\hline Section 16 & Earnings per share & IAS 33 \\
\hline Section 17 & Events after the balance sheet date & IAS 10 \\
\hline Section 18 & $\begin{array}{l}\text { Provisions, contingent liabilities and } \\
\text { contingent assets }\end{array}$ & IAS 37 \\
\hline Section 19 & $\begin{array}{l}\text { Accounting policies, changes in accounting } \\
\text { estimates and errors }\end{array}$ & IAS 8 \\
\hline Section 20 & Leases & IAS 17 \\
\hline Section 21 & Related party disclosures & IAS 24 \\
\hline Section 22 & Segment reporting & IAS 14 \\
\hline Section 23 & $\begin{array}{l}\text { Disclosures in the financial statements of } \\
\text { banks and similar financial institutions }\end{array}$ & IAS 30 \\
\hline Section 24 & Construction contracts & IAS 11 \\
\hline Section 25 & Discontinuing operations & IAS $35^{* *}$ \\
\hline Section 26 & $\begin{array}{l}\text { Accounting for government grants and } \\
\text { disclosure of government assistance }\end{array}$ & IAS 20 \\
\hline Section 27 & Investment property & IAS 40 \\
\hline
\end{tabular}

Notes: *IAS 22 was superseded by IFRS 3, effective 31 March 2004.

**IAS 35 was superseded by IFRS 5, effective 2005.

Source: SPK (CMB) (2003) 
Table 8 The accounting standards of the Capital Market Board (CMB) - Series XI, No. 25 (continued)

\begin{tabular}{lcc}
\hline Section Number & Description of CMB Standards & IFRS \\
\hline Section 28 & Income taxes & IAS 12 \\
Section 29 & Employee benefits & IAS 19 \\
Section 30 & Accounting and reporting by retirement & benefit plans \\
Section 31 & Agriculture & IAS 26 \\
Section 32 & The issuance of financial statements and & IAS 41 \\
Section 33 & submitting to stock exchange & - \\
Section 34 & First time adoption of the standards & - \\
\hline
\end{tabular}

Notes: *IAS 22 was superseded by IFRS 3, effective 31 March 2004.

**IAS 35 was superseded by IFRS 5, effective 2005.

Source: SPK (CMB) (2003)

In summary, financial reporting in Turkey has a multi-institutional structure. Turkish companies prepare their financial reports according to different set of accounting standards depending on the nature of their business and their shareholding structure. Following is a table summarising the reporting requirements of different companies:

Table 9 Reporting requirements in Turkey

\begin{tabular}{lc}
\hline Type of the company & Accounting standard enforced \\
\hline Private large companies & Old CMB standards (Series XI, No. 1 and its \\
& amendments) \\
Publicly owned (listed companies) & New CMB standards (Series XI No. 25 and its \\
Brokerage companies & amendments) \\
& New CMB standards (Series XI No. 25 and its \\
Banks and financial institutions & amendments) \\
\hline
\end{tabular}

Table 10 provides a list of IFRS and IAS issued by IASB $^{16}$ and by TASB $^{17}$ by the end of 2007. As we can observe from the table, it appears that TASB has aligned itself with IASB and follows closely the amendments and revisions to the standards. Since Turkey is a civil law country, TASB has been endorsed by law to issue new standards and to make the necessary changes in the standards to align them with the IFRS/IAS. The new standards or changes or revisions in the standards should be published in the Official Gazette to be effective. TASB board members closely follow the developments at IASB and try to take measures to quicken the process of adoption that has several steps: translation into Turkish, acceptance by Board and issuance. However, the main hurdle currently is the lack of enforcement power of TAS. If the draft Commercial Code passes as is, then TAS will be compulsory for all companies. Until then, TAS are required by BRSA and accepted by CMB. 
Table 10 IFRS/IAS and TFRS/TAS comparison

\begin{tabular}{|c|c|c|c|c|c|}
\hline \multirow{2}{*}{$\begin{array}{l}\text { Standards* } \\
\text { /Issued by }\end{array}$} & & $I A S B$ & $I A S B$ & $T A S B$ & $T A S B$ \\
\hline & & $\begin{array}{l}\text { Issued/ } \\
\text { revised }\end{array}$ & Effective** & Issued & Effective** \\
\hline Framework & & $1989 / 2001$ & $1989 / 2001$ & 2005 & 1 Jan 2006 \\
\hline \multicolumn{6}{|l|}{ IFRSs: } \\
\hline IFRS 1 & $\begin{array}{c}\text { First-time } \\
\text { adoption of IFRS }\end{array}$ & $\begin{array}{c}2003 \\
\text { (amended in } \\
2005)\end{array}$ & $\begin{array}{l}1 \text { Jan } 2004 \\
1 \text { Jan } 2006\end{array}$ & $\begin{array}{c}2006 \\
\text { (amended } \\
\text { in 2007) }\end{array}$ & $\begin{array}{l}\text { 1 Jan } 2006 \\
\text { 1 Jan } 2007\end{array}$ \\
\hline IFRS 2 & $\begin{array}{l}\text { Share-based } \\
\text { payment }\end{array}$ & 2004 & 1 Jan 2005 & 2006 & 1 Jan 2006 \\
\hline IFRS 3 & $\begin{array}{l}\text { Business } \\
\text { combinations }\end{array}$ & 2004 & 31 Mar 2004 & 2006 & 1 Jan 2006 \\
\hline IFRS 4 & $\begin{array}{l}\text { Insurance } \\
\text { contracts }\end{array}$ & $\begin{array}{c}2004 \\
\text { (amended } \\
2005 \text { ) }\end{array}$ & $\begin{array}{l}1 \text { Jan } 2005 \\
1 \text { Jan } 2006\end{array}$ & $\begin{array}{c}2006 \\
\text { (amended } \\
\text { in 2007) }\end{array}$ & $\begin{array}{l}\text { 1 Jan } 2006 \\
\text { 1 Jan } 2007\end{array}$ \\
\hline IFRS 5 & $\begin{array}{l}\text { Non-current } \\
\text { assets held for } \\
\text { sale and } \\
\text { discontinued } \\
\text { operations }\end{array}$ & 2004 & 1 Jan 2005 & 2006 & 1 Jan 2006 \\
\hline IFRS 6 & $\begin{array}{c}\text { Exploration for } \\
\text { and evaluation of } \\
\text { mineral resources }\end{array}$ & 2004 & 1 Jan 2006 & 2006 & 1 Jan 2006 \\
\hline IFRS 7 & $\begin{array}{l}\text { Financial } \\
\text { instruments: } \\
\text { disclosures }\end{array}$ & 2005 & 1 Jan 2007 & 2007 & 1 Jan 2007 \\
\hline IFRS 8 & $\begin{array}{l}\text { Operating } \\
\text { segments }\end{array}$ & 2006 & 1 Jan 2009 & 2007 & 1 Jan 2009 \\
\hline \multicolumn{6}{|l|}{ IASs: } \\
\hline IAS 1 & $\begin{array}{l}\text { Presentation of } \\
\text { financial } \\
\text { statements }\end{array}$ & $\begin{array}{c}2003 \\
\text { (amended } \\
2005,2007)\end{array}$ & $\begin{array}{l}1 \text { Jan } 2005 \\
1 \text { Jan } 2007 \\
1 \text { Jan } 2009\end{array}$ & $\begin{array}{c}2005 \\
\text { (amended } \\
\text { in 2006 } \\
\text { and 2007) }\end{array}$ & $\begin{array}{l}\text { 1 Jan } 2006 \\
1 \text { Jan } 2007\end{array}$ \\
\hline IAS 2 & Inventories & 2003 & 1 Jan 2005 & $\begin{array}{c}2005 \\
\text { (amended } \\
\text { in 2006) }\end{array}$ & $\begin{array}{l}1 \text { Jan } 2006 \\
\text { (amendment } \\
\text { as well) }\end{array}$ \\
\hline IAS 7 & $\begin{array}{l}\text { Cash flow } \\
\text { statements }\end{array}$ & 1992 & 1 Jan 1994 & $\begin{array}{c}2005 \\
\text { (amended } \\
\text { in 2007) }\end{array}$ & $\begin{array}{l}\text { 1 Jan } 2006 \\
\text { 1 Jan } 2007\end{array}$ \\
\hline
\end{tabular}

Notes: *TAS follows the same numbers, e.g., IAS 1 is TMS 1 and IFRS 1 is TFRS 1.

**Annual periods beginning on or after this date. 
Table 10 IFRS/IAS and TFRS/TAS comparison (continued)

\begin{tabular}{|c|c|c|c|c|c|}
\hline \multirow{2}{*}{$\begin{array}{l}\text { Standards* } \\
\text { /Issued by }\end{array}$} & & $I A S B$ & $I A S B$ & $T A S B$ & $T A S B$ \\
\hline & & $\begin{array}{l}\text { Issued/ } \\
\text { revised }\end{array}$ & Effective** & Issued & Effective** \\
\hline Framework & & $1989 / 2001$ & $1989 / 2001$ & 2005 & 1 Jan 2006 \\
\hline \multicolumn{6}{|l|}{ IASs: } \\
\hline IAS 8 & $\begin{array}{c}\text { Accounting } \\
\text { policies, changes } \\
\text { in accounting } \\
\text { estimates and } \\
\text { errors }\end{array}$ & 2003 & 1 Jan 2005 & $\begin{array}{c}2005 \\
\text { (amended } \\
\text { in 2007) }\end{array}$ & $\begin{array}{l}\text { 1 Jan } 2006 \\
1 \text { Jan } 2007\end{array}$ \\
\hline IAS 10 & $\begin{array}{l}\text { Events after the } \\
\text { balance sheet date }\end{array}$ & 2003 & 1 Jan 2005 & $\begin{array}{c}2005 \\
\text { (amended } \\
\text { in 2007) }\end{array}$ & $\begin{array}{l}\text { 1 Jan } 2006 \\
1 \text { Jan } 2007\end{array}$ \\
\hline IAS 11 & $\begin{array}{l}\text { Construction } \\
\text { contracts }\end{array}$ & 1993 & 1 Jan 1995 & 2005 & 1 Jan 2006 \\
\hline IAS 12 & Income taxes & $\begin{array}{c}1996 \\
\text { (amended } \\
2000)\end{array}$ & $\begin{array}{c}1998 \\
1 \text { Jan } 2001\end{array}$ & $\begin{array}{c}2006 \\
\text { (amended } \\
\text { in } 2006 \\
\text { and 2007) }\end{array}$ & $\begin{array}{l}\text { 1 Jan } 2006 \\
1 \text { Jan } 2007\end{array}$ \\
\hline IAS 16 & $\begin{array}{l}\text { Property, plant } \\
\text { and equipment }\end{array}$ & 2003 & 1 Jan 2005 & 2005 & 1 Jan 2006 \\
\hline IAS 17 & Leases & 2003 & 1 Jan 2005 & $\begin{array}{c}2006 \\
\text { (amended } \\
\text { in 2007) }\end{array}$ & $\begin{array}{l}1 \text { Jan } 2006 \\
1 \text { Jan } 2007\end{array}$ \\
\hline IAS 18 & Revenue & $\begin{array}{c}1993 \\
\text { (amended } \\
1998)\end{array}$ & $\begin{array}{l}1 \text { Jan } 1995 \\
1 \text { Jan } 2001\end{array}$ & 2005 & 1 Jan 2006 \\
\hline IAS 19 & $\begin{array}{l}\text { Employee } \\
\text { benefits }\end{array}$ & 2004 & 1 Jan 2006 & 2006 & 1 Jan 2006 \\
\hline IAS 20 & $\begin{array}{l}\text { Accounting for } \\
\text { government } \\
\text { grants and } \\
\text { disclosure of } \\
\text { government } \\
\text { assistance }\end{array}$ & $\begin{array}{c}1983 \\
\text { (reformatted } \\
1984)\end{array}$ & 1 Jan 1984 & 2005 & 1 Jan 2006 \\
\hline IAS 21 & $\begin{array}{c}\text { The effects of } \\
\text { changes in } \\
\text { foreign exchange } \\
\text { rates }\end{array}$ & $\begin{array}{l}\text { 2003, Nov } \\
2005\end{array}$ & 1 Jan 2005 & $\begin{array}{c}2005 \\
\text { (amended } \\
\text { in 2007) }\end{array}$ & $\begin{array}{l}1 \text { Jan } 2006 \\
1 \text { Jan } 2007\end{array}$ \\
\hline IAS 23 & Borrowing costs & 2007 & 1 Jan 2009 & $\begin{array}{l}2005 \\
\text { (revised } \\
\text { in 2007) }\end{array}$ & $\begin{array}{l}1 \text { Jan } 2006 \\
1 \text { Jan } 2009\end{array}$ \\
\hline
\end{tabular}

Notes: *TAS follows the same numbers, e.g., IAS 1 is TMS 1 and IFRS 1 is TFRS 1.

**Annual periods beginning on or after this date. 
Table 10 IFRS/IAS and TFRS/TAS comparison (continued)

\begin{tabular}{|c|c|c|c|c|c|}
\hline \multirow{2}{*}{$\begin{array}{l}\text { Standards* } \\
\text { /Issued by }\end{array}$} & & $I A S B$ & $I A S B$ & $T A S B$ & $T A S B$ \\
\hline & & $\begin{array}{l}\text { Issued/ } \\
\text { revised }\end{array}$ & Effective** & Issued & Effective** \\
\hline Framework & & $1989 / 2001$ & $1989 / 2001$ & 2005 & 1 Jan 2006 \\
\hline \multicolumn{6}{|l|}{ IASs: } \\
\hline IAS 24 & $\begin{array}{l}\text { Related party } \\
\text { disclosures }\end{array}$ & 2003 & 1 Jan 2005 & 2005 & 1 Jan 2006 \\
\hline IAS 26 & $\begin{array}{l}\text { Accounting and } \\
\text { reporting by } \\
\text { retirement benefit } \\
\text { plans }\end{array}$ & $\begin{array}{c}1987 \\
\text { (reformatted } \\
1994)\end{array}$ & 1 Jan 1990 & 2006 & 1 Jan 2006 \\
\hline IAS 27 & $\begin{array}{l}\text { Consolidated and } \\
\text { separate financial } \\
\text { statements }\end{array}$ & 2003 & 1 Jan 2005 & 2005 & 1 Jan 2006 \\
\hline IAS 28 & $\begin{array}{l}\text { Investments in } \\
\text { associates }\end{array}$ & 2003 & 1 Jan 2005 & 2005 & 1 Jan 2006 \\
\hline IAS 29 & $\begin{array}{c}\text { Financial } \\
\text { reporting in } \\
\text { hyperinflationary } \\
\text { economies }\end{array}$ & $\begin{array}{c}1989 \\
\text { (reformatted } \\
1994)\end{array}$ & 1 Jan 1990 & 2005 & 1 Jan 2006 \\
\hline IAS 31 & $\begin{array}{l}\text { Interests in joint } \\
\text { ventures }\end{array}$ & 2003 & 1 Jan 2005 & 2005 & 1 Jan 2006 \\
\hline IAS 32 & $\begin{array}{l}\text { Financial } \\
\text { instruments: } \\
\text { presentation }\end{array}$ & 2003 & 1 Jan 2005 & $\begin{array}{c}2006 \\
\text { (amended } \\
\text { in 2007) }\end{array}$ & $\begin{array}{l}1 \text { Jan } 2006 \\
1 \text { Jan } 2007\end{array}$ \\
\hline IAS 33 & $\begin{array}{l}\text { Earnings per } \\
\text { share }\end{array}$ & 2003 & 1 Jan 2005 & $\begin{array}{c}2006 \\
\text { (amended } \\
\text { in 2007) }\end{array}$ & $\begin{array}{l}1 \text { Jan } 2006 \\
1 \text { Jan } 2007\end{array}$ \\
\hline IAS 34 & $\begin{array}{l}\text { Interim financial } \\
\text { reporting }\end{array}$ & 1998 & 1 July 1999 & 2006 & 1 Jan 2006 \\
\hline IAS 36 & $\begin{array}{l}\text { Impairment of } \\
\text { assets }\end{array}$ & 2004 & Mar 2004 & $\begin{array}{c}2006 \\
\text { (amended } \\
\text { in 2007) }\end{array}$ & $\begin{array}{l}1 \text { Jan } 2006 \\
1 \text { Jan } 2007\end{array}$ \\
\hline IAS 37 & $\begin{array}{c}\text { Provisions, } \\
\text { contingent } \\
\text { liabilities and } \\
\text { contingent assets }\end{array}$ & $\begin{array}{c}1998 \\
\text { (exposure } \\
\text { draft revisions } \\
\text { 2005) }\end{array}$ & $\begin{array}{c}\text { 1 July } 1999 \\
\text { 30 June } 2005\end{array}$ & $\begin{array}{c}2006 \\
\text { (amended } \\
\text { in 2007) }\end{array}$ & $\begin{array}{l}1 \text { Jan } 2006 \\
1 \text { Jan } 2007\end{array}$ \\
\hline IAS 38 & Intangible assets & 2004 & Mar 2004 & $\begin{array}{c}2006 \\
\text { (amended } \\
\text { in 2007) }\end{array}$ & $\begin{array}{l}\text { 1 Jan } 2006 \\
1 \text { Jan } 2007\end{array}$ \\
\hline
\end{tabular}

Notes: *TAS follows the same numbers, e.g., IAS 1 is TMS 1 and IFRS 1 is TFRS 1.

**Annual periods beginning on or after this date. 
Table 10 IFRS/IAS and TFRS/TAS comparison (continued)

\begin{tabular}{|c|c|c|c|c|c|}
\hline \multirow{2}{*}{$\begin{array}{l}\text { Standards* } \\
\text { /Issued by }\end{array}$} & & $I A S B$ & $I A S B$ & $T A S B$ & $T A S B$ \\
\hline & & $\begin{array}{l}\text { Issued/ } \\
\text { revised }\end{array}$ & Effective** & Issued & Effective** \\
\hline Framework & & $1989 / 2001$ & $1989 / 2001$ & 2005 & 1 Jan 2006 \\
\hline \multicolumn{6}{|l|}{ IASs: } \\
\hline IAS 39 & $\begin{array}{c}\text { Financial } \\
\text { instruments: } \\
\text { recognition and } \\
\text { measurement }\end{array}$ & $\begin{array}{c}2003 \\
\text { (amended } \\
2004,2005)\end{array}$ & $\begin{array}{l}1 \text { Jan } 2005 \\
1 \text { Jan } 2006\end{array}$ & $\begin{array}{c}2006 \\
\text { (amended } \\
\text { in 2007) }\end{array}$ & $\begin{array}{l}1 \text { Jan } 2006 \\
1 \text { Jan } 2007\end{array}$ \\
\hline IAS 40 & $\begin{array}{l}\text { Investment } \\
\text { property }\end{array}$ & 2003 & 1 Jan 2005 & $\begin{array}{c}2006 \\
\text { (amended } \\
\text { in 2007) }\end{array}$ & $\begin{array}{l}\text { 1 Jan } 2006 \\
\text { 1 Jan } 2007\end{array}$ \\
\hline IAS 41 & Agriculture & 2000 & 1 Jan 2003 & $\begin{array}{c}2006 \\
\text { (amended } \\
\text { in 2007) }\end{array}$ & $\begin{array}{l}\text { 1 Jan } 2006 \\
\text { 1 Jan } 2007\end{array}$ \\
\hline
\end{tabular}

Notes: *TAS follows the same numbers, e.g., IAS 1 is TMS 1 and IFRS 1 is TFRS 1.

**Annual periods beginning on or after this date.

\section{Conclusions}

This study intends to shed some lights on the 'growing tendency towards harmonisation with IFRS around the world' and 'evidence of internationalisation from Turkey'. To our knowledge, this study is the first attempt to compare the global adoption efforts for both the publicly traded and private companies.

We first briefly discussed the convergence issue and the efforts of conversion globally. Conversion is expected to benefit the multinational companies and international investors mainly. However, a major criticism that appears after 2005 is the presentation of the profit of the companies. The study conducted by Ernst \& Young in 2006 to report the initial observations on the implementation of IFRS states that the national identity of the financial statements with respect to the way of presentation is retained (Ernst \& Young, 2006). Allister Wilson, a senior partner in Ernst \& Young indicates that 'Implementation has been a resounding success, but hasn't necessarily brought greater comparability' (Bruce, 2006).

However, despite its drawbacks, adoption of IFRS is a necessity of today's global capital markets, for international economic activities have been increasing at a very rapid rate. Because of the need of convergence, the harmonisation attempts towards IFRS around the world gained momentum, especially in the USA, Canada, the EU, Asia-Pacific countries and in Turkey.

As of the end of 2007, several countries around the world are in the process of adopting IFRS. We explored whether the legal system or the development stage of the stock market have any effect on the acceptance and adoption of IFRS. We used MSCI-Barra emerging market, developing market and G7 countries as our sample. We found that both the legal system and stock market development stage influence the permission or requirement of IFRS for the unlisted (private) companies. However, it appears that the legal system does not have an effect on the permission or the requirement 
of IFRS for the domestic listed companies. The increased cross border capital movements and international investments may have already globalised the financial reporting of listed companies, therefore environmental effects on financial reporting may have spontaneously disappeared.

Finally, we discussed Turkey's endeavours to IFRS adoption. We chose to study the Turkish experience mainly because of the high foreign interest and her willingness to adopt the IAS. Turkey has various accountancy or regulatory bodies, each of which regulates a different type of company. Nevertheless, each of the accounting regulators, except for the tax regulators, has taken steps to converge to IFRS by translating them into Turkish. IFRS, as published by IASB, is permitted for the publicly traded companies. Furthermore, if the draft Commercial Code is promulgated, then TFRS/TAS, which are exact translations of corresponding IFRS, will become mandatory for all companies.

Other cultural and economic factors besides the legal system and stock market characteristics affect the choice to adopt the IFRS. Recent research in developing markets and Europe have shown that cultural factors affect the adoption of IFRS (Zeghal and Mhedhbi, 2006; Lainez and Gasca, 2006; Larson and Street, 2004). However, we need more country research on the issue of why some countries accept IFRS as is, while others need modifications not only for publicly traded companies but for private companies as well. Following, we may even question whether modifications made by several countries should be converged into the existing IFRS.

\section{References}

Aksu, M. and Kosedag, A. (2005) The Relationship between Transparency \& Disclosure and Firm Performance in the ISE: Does IFRS Adoption Make a Difference?, Graduate School of Management, Sabanci University, Turkey, available at http://people.sabanciuniv.edu/ maksu/papers/EFMA_AAA06tdP2.pdf\#search='IFRS\%20survey\%20in\%20Turkey'.

Andersen, BDO, Deloitte, Ernst \& Young, Grant Thornton, KPMG and PWC (2001) Introducing GAAP 2001, available at http://www.pwc.com/Extweb/ncsurvres.nsf/docid/E0760809FFD67E9485256CD900568C26.

Anil, D. (2000) Accounting Standards Regarding Presentation of Financial Statements and Turkish Financial Reporting System, Marmara University, Istanbul.

Bank for International Settlements (BIS) (2006) Basel II: Revised International Capital Framework, available at http://www.bis.org/publ/bcbsca.htm.

Basoglu, B. and Goma, A. (2000) International Accounting Standards and Selected Middle East Stock Exchanges, Manhattan College, available at http://www.sba.luc.edu/orgs/meea/volume4/Basoglu\%20Revised.htm.

Bruce, R. (2006) 'To simplicity via complexity-international financial reporting standards', The Financial Times, 6 September.

Choi, F.D.S., Frost, C.A. and Meek, G.K. (2002) International Accounting, 4th ed., Prentice-Hall.

Day, J.M. (2002) International Developments: Convergence and You, available at $\mathrm{http} / / / \mathrm{www} . \mathrm{sec}$.gov/news/speech/spch121302jmd.htm.

Deloitte (2006a) IFRS in your Pocket 2006, available at www.iasplus.com.

Deloitte (2006b) Canada, available at http://www.iasplus.com/country/canada.htm.

Ernst \& Young (2006) Observations on the Implementation of IFRS, available at www.ey.com/za. 
European Union (2002) Regulation (EC) No. 1606/2002 of the European Parliament and of the council of 19 July 2002 on the application of international accounting standards, Official Journal L243, 11 September, pp.1-4

FASB (2006) Facts about FASB, available at http://www.fasb.org/facts/index.shtml.

Flower, J. (1997) 'The future shape of harmonization: the UE versus the IASC versus the SEC', The European Accounting Review, Vol. 6, No. 2, pp.281-303.

Foster, M.N. (1993) The FASB and the Capital Markets, available at http://www.fasb.org/articles\&reports/Foster_FASBReport.pdf.

Graff, M. (2005) 'Law and finance: common-law and civil-law countries compared', KOF-Swiss Institute for Business Cycle Research, Working papers-no. 99, February.

Harvey, C.R. (1995) 'Predictable risk and returns in emerging markets, The Review of Financial Studies, Vol. 8, No. 3, pp.773-816.

Herdman, R.K. (2002) Moving Toward the Globalization of Accounting Standards, available at www.sec.gov/news/speech/spch554.htm.

Hewitt Investment Group (2005) Market Perspective December 2005, available at http://www.hewittinvest.com/pdf/12012005CMP.pdf.

Holzman, O.J. and Robinson, T. (2004) 'FASB/GAAP - international convergence', Journal of Corporate Accounting and Finance, Vol. 15, No. 5, pp.87-90.

IASB (2006) 'A roadmap for convergence between IFRSs and US GAAP 2006 to 2008, IASB Insight, pp.4-6, available at www.deloiteaudit.com (accessed on May 2006).

Ibis, C. and Ozkan, S. (2006) 'Uluslararasi Finansal Raporlama Standardlari (IFRS)'e genel bakis', Mali Cozum, Vol. 74, pp.25-43.

Katz, J.G. (2000) SEC Concept Release: International Accounting Standards, available at http://www.sec.gov/rules/concept/s70400/deloitt1.htm.

La Porta, R., Lopez-De-Silanes, F., Shleifer, A. and Vishny, R.W. (1997) 'Legal determinants of external finance', Journal of Finance, Vol. 52, pp.1131-1150.

Lainez, J.A. and Gasca, M. (2006) 'Obstacles to the harmonization process in the European Union: the influence of culture', International Journal of Accounting, Auditing and Performance Evaluation, Vol. 3, No. 1, pp.68-97.

Larson, R.K. and Street, D.L. (2004) 'Convergence with IFRS in an expanding Europe: progress and obstacles identified by large accounting firms' survey', Journal of International Accounting, Auditing and Taxation, Vol. 13, No. 2, pp.89-119.

Mazars (2005) IFRS 2005 European Survey, available at http://www.mazars.com/pdf/Enquete_IFRS_2005_UK.pdf.

Middlemiss, J. (2006) 'Going global', CA Magazine, available at $\mathrm{http}: / /$ www.camagazine.com/index.cfm/ci_id/30965/la_id/1.htm.

Murtaza, A.M. (2006) International financial reporting standards and accounting practices in the Gulf countries, AAA North East Meeting Presentation, April.

Peavy, D.E. and Webster, S.K. (1990) 'Is GAAP the gap to international market?, Management Accounting.Vol. 72, pp.31-35.

Perera, M.H.B (1989) 'Accounting in developing countries: a case for localized uniformity', British Accounting Review, Vol. 21, pp.141-158.

Petreski, M. (2006) 'The impact of international accounting standards on firms', AAA Financial Accounting and Reporting Section (FARS) Meeting, available at $\mathrm{http}: / /$ ssrn.com/abstract=901301.

PricewaterhouseCoopers (2006) IFRS: the European Investors' View, available at www.pwcglobal.com.

Schipper, K. (2005) 'The introduction of international accounting standards in Europe: implications for international convergence, European Accounting Review, Vol. 14, No. 1, pp.101-126. 
Sermaye Piyasasi Kurulu (SPK) or (CMB) (2003) Seri: XI No: 25, available at http://www.spk.gov.tr/teblig/files/SeriXI_No25.pdf.

Sermaye Piyasasi Kurulu (SPK) (2006) 2001-2006 Yillari Arasinda Gerceklestirilen Duzenlemeler', May, available at http://www.spk.gov.tr/\#.

Simga-Mugan, C. (1995) 'Accounting in Turkey', The European Accounting Review, Vol. 4, No. 2 , pp.351-371.

Simga-Mugan, C. and Akman, N. (2007) 'Review of practical implementation issues of international financial reporting standards: case study of Turkey', (UNCTAD) 24th Session of Intergovernmental Working Group of Experts on International Standards of Accounting and Reporting (ISAR), Geneva, 30 October-1 November, available at $\mathrm{http}: / /$ www.metu.edu.tr/ mugan/proceedings.htm (accessed on 21 December).

Simga-Mugan, C. and Hosal-Akman, N. (2005) 'Convergence to international financial reporting standards: the case of Turkey', International Journal Accounting, Auditing, and Performance Evaluation, Vol. 2, Nos. 1/2, pp.127-139.

Taylor, M.E., Evans, T.G. and Joy, A.C. (1986) 'The impact of IASC accounting standards on comparability and consistency of international reporting practices', International Journal of Accounting Education and Research, Vol. 22, No. 1, pp.1-9.

Turkish Accounting Standard Board (TASB) (2006) Turkish Accounting Standards, available at http://www.tmsk.org.tr/.

Turkish Treasury (2005) Table of the Companies with Foreign Capital, available at http://www.hazine.gov.tr/TABLOLAR_20060217.xls.

Turkish Treasury (2006) Foreign Direct Investment Information Bulletin, February, available at http://www.hazine.gov.tr/YBS_20060217.pdf.

Van Helleman, J. and Slomp, S. (2002) 'The changeover to international accounting standards in Europe', Betriebswirtschaftliche Forschung and Praxis, Vol. 3, pp.213-229.

Zeghal, D. and Mhedhbi, K. (2006) 'An analysis of the factors affecting the adoption of international accounting standards by developing countries', The International Journal of Accounting, Vol. 41, pp.373-386.

\section{Notes}

1 Copeland, M.V. (2007) The mighty micro-multinational, available at http://money.cnn.com/magazines/business2/business2_archive/2006/07/01/8380230/index.htm (accessed on 28 December).

$2 \mathrm{http} / / / \mathrm{www}$. turkcell.com.tr/raporlar/faaliyetraporu2000bolum4.pdf, http://www.turkcell.com.tr/raporlar/annualreport2000auditorsreport.pdf (accessed on 28 December 2007).

3 http://www.iasb.org/IFRS+Summaries/IFRS+and+IAS+Summaries++English/IFRS+and+IAS+Summaries-+English.htm (accessed on 28 December 2007).

4 http://www.iasb.org/About+Us/About+the+Foundation/Constitution.htm (accessed on 28 December 2007).

5 http://www.iasb.org/About+Us/About+IASB/IFRS+Around+the+World.htm (accessed on 28 December 2007).

$6 \mathrm{http} / / /$ www.fasb.org/st/ (accessed on 27 December 2007).

7 http://www.turkcell.com.tr/en/investorRelations/financialandOperationalInformation/ incomeStatementAnalysis (accessed on 28 December 2007).

8 http://www.sec.gov/news/press/2007/2007-235.htm (accessed on 25 December 2007).

9 http://www.iasb.org/About+Us/About+IASB/No+new+major+standards+to+be+effective +before+ 2009.htm (accessed on 25 December 2007). 
$10 \mathrm{http} / / / \mathrm{www} . \mathrm{mscibarra} . c 0 m /$ products/indices/equity/coverage.jsp, http://www.mscibarra.com/resources/pdfs/coverage_matrix.pdf

$11 \mathrm{http} / / / \mathrm{www}$. iasplus.com/country/useias.htm, copyright (C) 2007 by Deloitte Touche Tohmatsu - November 2007.

12 http://www.hewittinvest.com/pdf/12012007CMP.pdf (accessed on 6 January 2008).

$13 \mathrm{http} / / / \mathrm{www} \cdot$ hewittinvest.com/pdf/12012007CMP.pdf (accessed on 6 January 2008).

14 http://www.spk.gov.tr/teblig/files/SeriXI_No25.pdf, Series XI No. 29

15 www.tasb.org.tr (accessed on 6 January 2008).

$16 \mathrm{http} / / /$ www.iasb.org/IFRS+Summaries/IFRS+and+IAS+Summaries++English/IFRS+and+IAS+Summaries-+English.htm (accessed on 6 January 2008).

17 www.tasb.org.tr (accessed on 6 January 2008). 